Bull. Fac. Agric., Cairo Univ., 70: 453-460 (2019).

\title{
PRODUCING YARNS FROM BLENDS OF CARD WASTES, RECYCLED FABRIC AND MEDIUM QUALITY COTTON
}

\author{
(Received: 7 .11.2019)
}

\author{
By \\ Hanan M. Arafa \\ Cotton Research Institute, Agricultural Research Center, Giza, Egypt.
}

\begin{abstract}
This investigation was conducted to produce open end rotor yarns from blends of card wastes, recycled fabrics and Giza 90 low grade FGF cotton in the spinning mill of North Africa Spinning Company El Sadat city, El Menoufea Governorate, Egypt. The card waste and recycled fibers couldn't be spun to $6 \mathrm{Ne}$ rotor yarns. Five blends of Giza 90 virgin fibers and these waste and recycled materials, at different blending ratios, were spun successfully to $8 \mathrm{Ne}, 10 \mathrm{Ne}$ and $12 \mathrm{Ne}$ open-end rotor yarns. Fiber and yarn quality measurements were determined. Giza 90 virgin fibers showed better length, length uniformity and tenacity with lower short fiber content compared to card waste and recycled materials although of its low grade. The results indicated that blending Giza 90 virgin fibers improved fiber and yarn quality of the blend specially when the ratio of Giza 90 increased in the blend.75\% Giza 90/ 25\% card waste or recycled fibers blends showed higher yarn strength and lower yarn CV\% and lower number of imperfections compared to the other blends while $33 \%$ Giza 90/ 33\% card waste/ $33 \%$ recycled fibers showed the lowest level of these yarn quality levels.
\end{abstract}

Key words: recycled fabric, blends of card wastes, cotton.

\section{INTRODUCTION}

Recycling is a way to process the used materials (waste) into new products to prevent waste of potentially useful materials. It reduces the consumption of fresh raw materials, energy usage, air pollution, water pollution, and land pollution Sharma and Joel (2017). Recycling textile waste can be further converted into the form of fiber for filling, recycled yarns, recycled woven and non woven fabrics (Yukesekkaya $e t$ al. 2016). Textile waste can arise at different production stages such as fibers, sliver, yarn and fabrics. Moreover, the used fabrics can be opened into fibers that could be used to produce products such as Knitwear, woven fabric and yarns cover clothes, blankets, towels, shirting, underwear, carpet, industrial roller cloth, electric cabling and in manufacturing of asbestos yarns and regenerated fibers (Saravanan ,2011).

Textile waste recycling becomes more important due to the continuously rising costs of natural and synthetic fibers, energy, and labor. As natural resources decrease, public awareness of recycling increases rapidly. The textile industry generates large amounts of waste with high potential for recycling therefore; a special market has formed for recycling of textile materials (Tereschenko,2012).

During the recycling procedure, harsh mechanical and / or chemical processes are applied to textile materials .In mechanical processing, fabric wastes are torn into individual fibers in tearing machines by harsh mechanical effects, while in case of chemical processing; thermoplastic waste materials are melted at high temperature. Both mechanical and chemical recycling could cause deterioration in physical and chemical properties of recycled materials (Bartolome et al., 2012 and Cornier, 2003).

The studies about blending recycled (recovered) fibers quality, cleaning behavior and processing of these materials are essential to deal with textile waste. In this concern, Babak and Safdar (2013) indicated that blending is used as a means of substituting a less expensive fiber for a highly priced one and to produce yarns with qualities that cannot be obtained by using one type of materials alone. Recovered raw materials can be blended with virgin cotton fibers either at blowroom or at draw frame. Generally, it is said that the earlier blending of fibers gives better blending. Furthermore, Stephan and Kuschel (1995) stated that 
recovered fibers from cotton waste can be used to produce blended yarns (cotton waste/ virgin fibers) in different portions. They added that the evaluation of recovered fibers characteristics enables the spinner to determine the optimum blend of (cotton waste/ virgin fibers), how to optimize machine setting in view of fiber/ machine interaction and how to eliminate quality problems before they appear in the final product. Wulfhorst (1984) concluded that up to $20 \%$ of recycled fibers can be blended with primary raw material without noticeable changes in the tenacity of the produced yarns. It is common in rotor spinning system to produce useful yarns from recycled fibers in different blend ratios with virgin materials. The blend ratio depends on the targeted yarn quality, raw material quality, machine running conditions and the total cost of the spun yarns (Nityanand ,1984). El nouby and Kamel (2007) reported that yarn tenacity, yarn elongation and yarn regularity of the recycled spun yarns decreased as the percentage of recycled fibers increased in the blend. Furthermore, Halimi et al. (2009) and Khan et al. (2015) found that higher percentage of virgin cotton in the blend always increase yarn strength, they added that homogeneity in blending is necessary to get higher yarn strength and low yarn imperfections.

Therefore, the main objectives of this research work was to study producing cheep open end rotor spun yarns from blends of recovered fibers, textile waste and virgin cotton fibers and studying the effect of blending ratio, and yarn count on the produced yarn strength, elongation, irregularity and imperfections

\section{MATERIALS AND METHODS}

The present study was carried out in the spinning mill of North Africa Spinning Company at El-Sadat city, Elmenofea Governorate, Egypt, using samples of fully good fair (FGF) lint grade of Giza 90 Egyptian cotton variety, card waste (flat strips from carding machines during processing in the spinning mill) and fibers obtained from recycled fabrics. Card waste and recycled fibers were obtained from the aforementioned company.

Giza 90 is used as virgin cotton to be a carrier and improving fiber and yarn quality when blending with card waste and fibers from the recycled fabrics under the following levels of blend proportions:

$50 \%$ Giza $90 / 50 \%$ card waste

$50 \%$ Giza 90 / $50 \%$ fibers from recycled fabrics
$75 \%$ Giza 90 / 25\% card waste

$75 \%$ Giza $90 / 25 \%$ fibers from recycled fabrics

$33.3 \%$ Giza $90 / 33.3 \%$ card waste / 33.3 fibers from recycled fabrics

$100 \%$ Giza 90 FGF (control)

Fiber quality properties of samples from the different raw materials and their blends were tested using Uster HVI Spectrum system at the labs of Fiber Research Department, Cotton, research Institute according to ASTM standard test method (D 5867 - 05) to obtain the following fiber quality measurements: upper half mean length (UHML) in mm., length uniformity index \% (UI \%), short fiber index \% (SFI\%), the tensile strength (g/tex), fiber elongation \%, micronaire value (Mike), maturity ratio (MR) and trash area \%.

Blending of the different materials was carried on the drawing frame in the first passage by using number of card slivers of each material to get the targeted blending ratio. Another drawing passage was used to improve the homogeneity of the blend. The linear density of card and draw slivers was $5.5 \mathrm{ktex}$. The second draw slivers were used to produce the rotor spun yarns. Ritter rotor spinning machine was used to produce $8 \mathrm{~s}, 10 \mathrm{~s}$ and $12 \mathrm{~s}$ yarn counts from the different blends. Rotor diameter was $55 \mathrm{~mm}$, rotor speed was $77000 \mathrm{rpm}$ at 5.5 twist multiplier.

Yarn strength and elongation \% of the spun yarns were tested by the USTER TENSORAPID according to Uster Manual (2001). Yarn irregularity and imperfections (neps, thin places and thick places) were determined using USTER tester 3 according to Uster Manual (2001). All yarn tests were carried out at the labs of El Seouf Spinning \& Weaving Company in Alexandria. All fiber and yarn tests were carried under controlled temperature $(20 \mathrm{C} \pm 2)$ and relative humidity $(65 \% \pm 2)$.

The obtained data were computed and subjected to statistical analysis as proposed by Snedecor and Cochran (1981) using SAS anova statistical analysis in completely randomized design with four replications. The LSD test at $5 \%$ level was employed to compare the different means.

\section{RESULTS AND DISCUSSION 3.1. Fiber quality of the different materials and blends \\ Subjecting the data of fiber quality measurements represent the different materials and blends to ANOVA statistical analysis}


revealed significant differences at $5 \%$ level between means of fiber quality measurements of Giza 90 (FGF), card waste, recycled fabric fibers and their blends. Data in Table (1) and Fig. (1) illustrates the different means of fiber quality measurements.

Although of its low grade, Giza 90 ( virgin fibers ) showed longer fibers $(28.2 \mathrm{~mm})$, more length uniformity $(83.5 \%)$ having lower short fiber index $(8.5 \%)$, having higher fiber tenacity (33.1 g / tex) and elongation (8.1\%) compared to card waste, recycled fabric fibers and their blends. Card waste recorded the least fiber length $(18.4 \mathrm{~mm})$, the least length uniformity $(70.1 \%)$ and the lowest tenacity $(22.0 \mathrm{~g} / \mathrm{tex})$, while showed the highest short fiber Index (17.8 $\%)$ and the highest trash area as well (1.41\%). Recycled fabric fibers showed longer fibers than the card waste $(21.5 \mathrm{~mm})$, higher length uniformity $(73.5 \%)$ and higher tenacity (24.6 $\mathrm{g} /$ tex) with lower short fiber index and fiber elongation than card waste but lower in all of these traits than Giza 90. These results indicated that card waste showed the lowest level of fiber quality among the studied materials.

Regarding the different blends, the results cleared that; fiber length, length uniformity and fiber tenacity increased and short fiber index decreased when the portion of Giza 90 fibers increased in the blend. Moreover, the blends contain Giza 90 and recycled fabric fibers were higher fiber quality than those consisted of Giza 90 and card waste under the same blending ratio. On the other hand, the blend 33\% Giza 90/ 33\% card waste and $33 \%$ recycled fabric fibers exhibited the lowest levels of fiber quality compared to the other blends. Elnouby and Kamal 2007, Halimi et al., (2009) and Khan et al. (2015) reported similar conclusions.

Since the objective of this research work was to study producing cheep open end rotor spun yarns from blends of recovered fibers, textile waste and low grade virgin cotton fibers (FGF). Besides studying the effect of blending ratio, and yarn count on the produced yarn strength, elongation, irregularity and imperfections, it is worthy to report that $8 \mathrm{Ne}$, $10 \mathrm{Ne}$ and $12 \mathrm{Ne}$ blended yarns were successfully spun from these blends, which could be considered a successful attempt to get more added values to these materials. Whilst, card waste and recycled fabric fibers failed to be spun to open end yarns even when processed to $6 \mathrm{Ne}$ yarn count, it led to very high number of ends down and could not run smoothly during processing.

Table (1): Means of fiber quality measurements for the different materials and their blends.

\begin{tabular}{|l|c|c|c|c|c|c|c|c|}
\hline \multicolumn{1}{|c|}{ Fiber properties } & Mike & MR & $\begin{array}{c}\text { UHM } \\
\text { mm }\end{array}$ & UI\% & SFI\% & $\begin{array}{c}\text { Tenacity } \\
\text { g/tex }\end{array}$ & $\begin{array}{c}\text { Elonga } \\
\text {-tion } \\
\text { \%aterials \& blends }\end{array}$ & $\begin{array}{c}\text { Tras } \\
\text { h } \\
\text { area }\end{array}$ \\
\hline Giza 90 (FGF) & 3.80 & 0.88 & 28.20 & 83.5 & 8.5 & 33.1 & 8.1 & 0.96 \\
\hline Card waste & 3.70 & 0.86 & 18.40 & 70.1 & 17.8 & 22.0 & 7.8 & 1.41 \\
\hline Recycled fabric fibers & 4.20 & 0.90 & 21.50 & 73.5 & 14.9 & 24.6 & 6.8 & 0.52 \\
\hline 50\% G90 / 50\% Card waste & 3.80 & 0.87 & 2410 & 77.5 & 13.7 & 27.5 & 8.0 & 1.30 \\
\hline 50\% G90/ 50\% Recycled fabric & 4.00 & 0.90 & 25.00 & 80.0 & 12.5 & 28.5 & 7.3 & 0.76 \\
\hline 75\% G90/ 25\% Card waste & 3.80 & 0.88 & 26.10 & 80.5 & 10.1 & 30 & 7.9 & 1.00 \\
\hline 75\% G90 / 25\% Recycled fibers & 3.90 & 0.90 & 26.50 & 81.1 & 9.8 & 31.0 & 7.5 & 0.80 \\
\hline $\begin{array}{l}\text { 33\% G90 / 33\% Card waste / } \\
\text { 33\% recycled fibers }\end{array}$ & 3.90 & 0.88 & 23.10 & 77.0 & 13.0 & 28.0 & 7.70 & 0.98 \\
\hline LSD 5\% & 0.12 & 0.04 & 0.46 & 1.12 & 0.73 & 0.88 & 0.53 & 0.16 \\
\hline
\end{tabular}



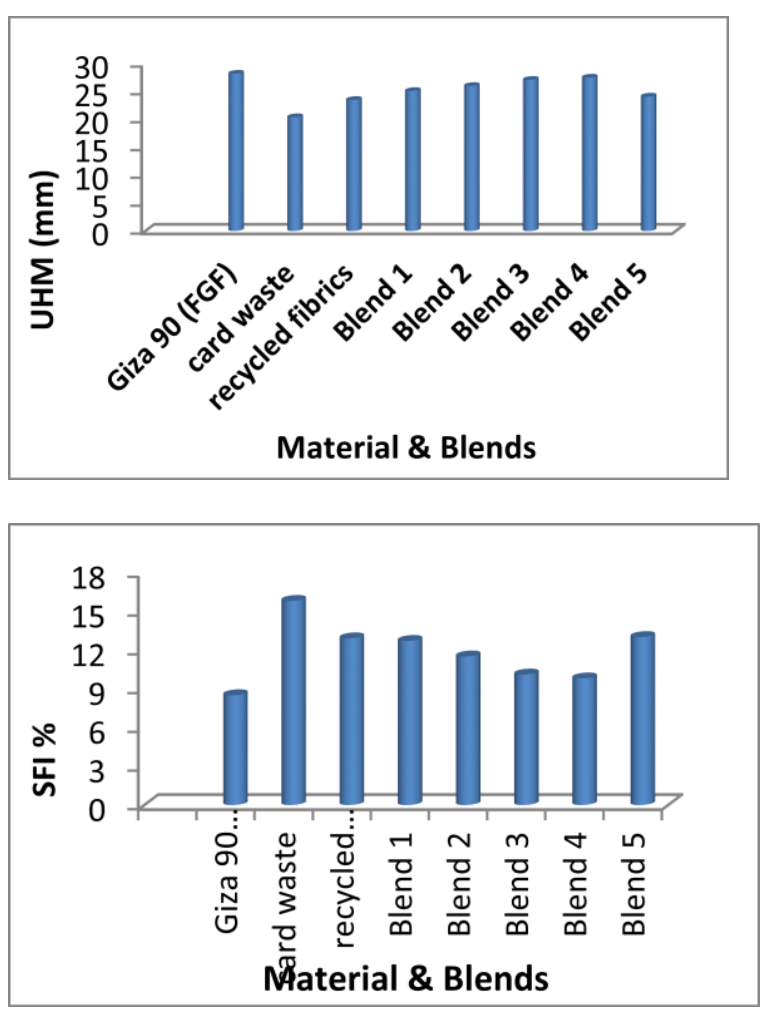
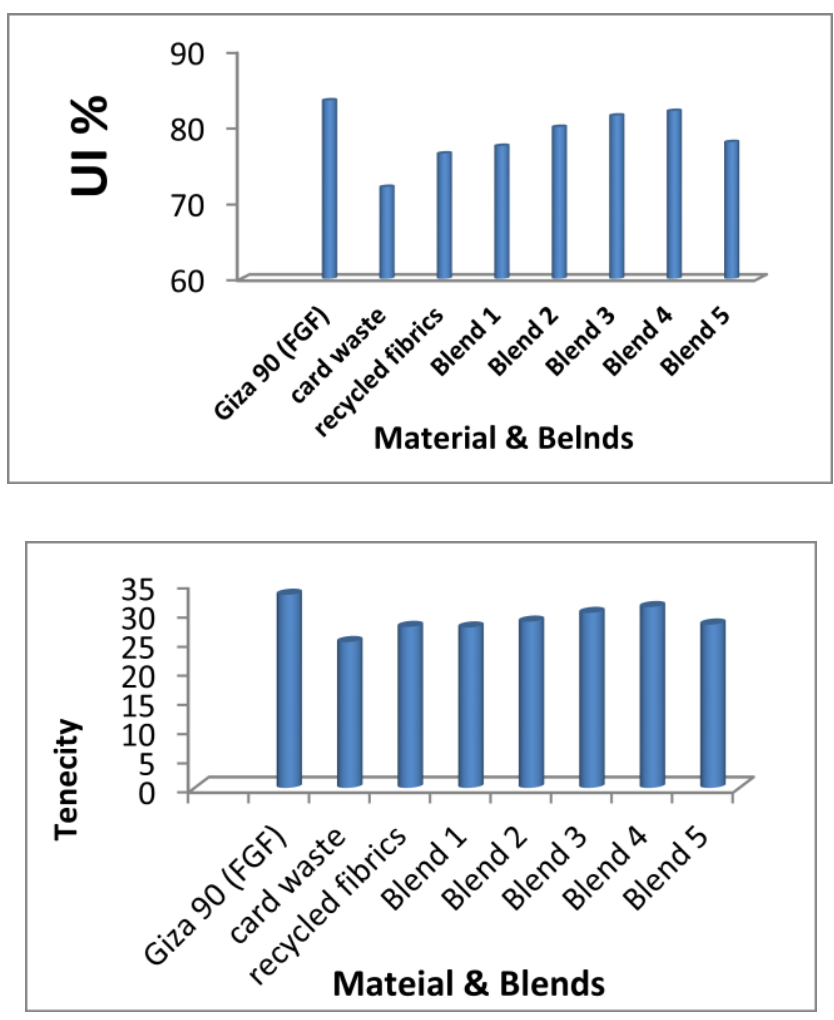

Fig.(1): Fiber quality measurements for the different materials and their blends.

\subsection{Effect of blend ratio and components on yarn quality of the spun yarns \\ Data concerning the effect of blending ratio} and its components on yarn quality properties are shown in Table (2) and 3 and illustrated in Fig. (2). The analysis of variance indicated that blend ratio and its components affected significantly most of the studied yarn quality properties. The obtained results led to the following conclusions:

The virgin fibers of Giza 90 produced yarns having higher strength, elongation and lower yarn cv\% (more uniform) and contain lower numbers of yarn imperfections; neps, thin and thick places than all the blends although of its low grade (FGF).

Comparing yarn quality properties of the different blends of Giza 90 / card waste and / or recycled fabric fibers, data in Tables $(2$ and, 3$)$ illustrated in Fig.(2) cleared that $75 \%$ Giza 90/ $25 \%$ card waste and $75 \%$ Giza $90 / 25 \%$ recycled fabric fibers showed insignificant differences in yarn strength, yarn elongation,

yarn CV\% but both of them produced yarns of higher quality levels as compared to the other blends. The recorded means of these yarn properties for the two mentioned blends were:
10.6 and $11.0 \mathrm{~g} /$ tex for yarn strength, 8.07 and $7.8 \%$ for yarn elongation and $14.23 \%$ and 14.07 for yarn CV\%. Moreover, the blends 50\% Giza 90 / 50\% card waste and 50\% Giza 90 / 50\% recycled fabric fibers showed significant differences in yarn strength being 8.94 and 9.64 g/tex, respectively, while, showed insignificant differences in yarn elongation and yarn $\mathrm{CV} \%$ to be, 7.47 and $7.27 \%$ for elongation and being, 16.07 and $15.57 \%$ for yarn CV\%.

The blend of 33\% Giza 90/ 33\% card waste/ $33 \%$ recycled fabric fibers showed the least yarn strength, the least yarn elongation and the highest yarn CV\% to be $8.81 \mathrm{~g} / \mathrm{tex}, 6.40 \%$ and $16.57 \%$ for the three yarn properties respectively. Concerning yarn imperfections; neps, thin and thick places, data in Table (3) and Fig. (2) revealed that all the blends of card waste and recycled fibers with Giza 90 virgin fibers showed significant high number of yarn imperfections, furthermore, the number of these imperfections increased as the ratio of the card waste and/or the recycled fabric fibers increased in the blend. Giza 90 virgin fibers showed the least number of these yarn imperfections, regardless of its low grade, it averaged 179.3, 
Table (2): Strength, elongation and CV\% for the yarns spun from blends of Giza 90, card waste and recycled fabric fibers.

\begin{tabular}{|c|c|c|c|c|c|c|c|c|c|c|c|c|}
\hline \multirow{2}{*}{$\begin{array}{l}\text { Yarn qualit } \\
\text { Materials and Blends }\end{array}$} & \multicolumn{3}{|c|}{ Yarn tenacity g/tex } & \multirow{2}{*}{ Mean } & \multicolumn{3}{|c|}{ Yarn elongation \% } & \multirow{2}{*}{ Mean } & \multicolumn{3}{|c|}{$\begin{array}{c}\text { Yarn uneveness } \\
\text { (C.V\%) }\end{array}$} & \multirow{2}{*}{ Mean } \\
\hline & $\begin{array}{c}\mathrm{Ne} \\
8\end{array}$ & $\begin{array}{l}\mathrm{Ne} \\
10\end{array}$ & $\begin{array}{l}\mathrm{Ne} \\
12\end{array}$ & & $\begin{array}{c}\mathrm{Ne} \\
8\end{array}$ & $\begin{array}{l}\mathrm{Ne} \\
10\end{array}$ & $\begin{array}{l}\mathrm{Ne} \\
12\end{array}$ & & $\begin{array}{c}\mathrm{Ne} \\
8\end{array}$ & $\begin{array}{l}\mathrm{Ne} \\
10\end{array}$ & $\begin{array}{l}\mathrm{Ne} \\
12\end{array}$ & \\
\hline $50 \%$ G90 / 50\% Card waste & 9.4 & 8.8 & 8.6 & 8.94 & 7.6 & 7.4 & 7.4 & 7.47 & 15.8 & 16.1 & 16.3 & 16.07 \\
\hline $50 \%$ G90 / 50\% Recycled fibers & 10.2 & 9.9 & 8.9 & 9.64 & 7.4 & 7.2 & 7.2 & 7.27 & 15.3 & 15.6 & 15.8 & 15.57 \\
\hline $75 \%$ G90 / 25\% Card waste & 11.2 & 10.7 & 9.9 & 10.60 & 8.3 & 8.1 & 7.8 & 8.07 & 14.0 & 14.2 & 14.5 & 14.23 \\
\hline $75 \%$ G90 / 25\% Recycled fibers & 11.6 & 10.9 & 10.5 & 11.00 & 8.0 & 7.8 & 7.8 & 7.87 & 13.8 & 14.1 & 14.3 & 14.07 \\
\hline $\begin{array}{l}\text { 33\% G90 / 33\% Card waste / } \\
\text { 33\% Recycled fibers }\end{array}$ & 9.1 & 8.7 & 8.6 & 8.81 & 6.6 & 6.3 & 6.3 & 6.40 & 16.2 & 16.8 & 16.7 & 16.57 \\
\hline Giza 90 (FGF) & 13.4 & 12.8 & 12.6 & 13.02 & 8.2 & 8.0 & 7.9 & 8.03 & 13.2 & 13.6 & 13.6 & 13.47 \\
\hline Mean & 10.8 & 10.3 & 9.86 & 10.34 & 7.68 & 7.47 & 7.40 & 7.52 & 14.7 & 15.07 & 15.2 & 14.99 \\
\hline LSD \% Blends & & & & 0.48 & & & & 0.38 & & & & 0.55 \\
\hline LSD\% Count & & & & 0.42 & & & & 0.32 & & & & 051 \\
\hline LSD\% Blends $x$ count & & & & 0.61 & & & & 0.57 & & & & 077 \\
\hline
\end{tabular}

Table (3): Number of imperfections; neps, thin and thick places for the yarns spun from blends of Giza 90, card waste and recycled fabric fibers.

\begin{tabular}{|c|c|c|c|c|c|c|c|c|c|c|c|c|}
\hline \multirow{2}{*}{$\begin{aligned} \text { properties } & \text { Yarn } \\
\text { Materials \& blends } & \end{aligned}$} & \multicolumn{3}{|c|}{ Neps / 1000m } & \multirow{2}{*}{ Mean } & \multicolumn{3}{|c|}{$\begin{array}{c}\text { Thin places / } \\
1000 \mathrm{~m}\end{array}$} & \multirow{2}{*}{ Mean } & \multicolumn{3}{|c|}{$\begin{array}{c}\text { Thick places / } \\
1000 \mathrm{~m}\end{array}$} & \multirow{2}{*}{ Mean } \\
\hline & $\begin{array}{l}\mathrm{Ne} \\
8\end{array}$ & $\begin{array}{l}\mathrm{Ne} \\
10\end{array}$ & $\begin{array}{l}\mathrm{Ne} \\
12\end{array}$ & & $\begin{array}{l}\mathrm{Ne} \\
8\end{array}$ & $\begin{array}{l}\mathrm{Ne} \\
10\end{array}$ & $\begin{array}{l}\mathrm{Ne} \\
12\end{array}$ & & $\begin{array}{r}\mathrm{Ne} \\
8\end{array}$ & $\begin{array}{l}\mathrm{Ne} \\
10\end{array}$ & $\begin{array}{l}\mathrm{Ne} \\
12\end{array}$ & \\
\hline $50 \%$ G90 / 50\% Card waste & 340 & 396 & 285 & 340.3 & 86 & 91 & 90 & 89.0 & 231 & 243 & 248 & 240.7 \\
\hline 50\% G90 / 50\% Recycled & 293 & 289 & 299 & 293.7 & 81 & 88 & 85 & 84.7 & 220 & 231 & 240 & 230.3 \\
\hline $75 \%$ G90 / 25\% Card waste & 229 & 235 & 268 & 244.0 & 65 & 70 & 70. & 68.3 & 196 & 210 & 207 & 204.3 \\
\hline $75 \%$ G90 / 25\% Recycled & 216 & 227 & 245 & 229.3 & 60 & 64 & 66 & 63.3 & 178 & 180 & 180 & 179.3 \\
\hline $\begin{array}{l}\text { 33\% G90 / 33\% Card waste } \\
\text { / 33\% Recycled fibrics }\end{array}$ & 354 & 378 & 360 & 364.0 & 100 & 100 & 110 & 103.3 & 240 & 271 & 273 & 261.3 \\
\hline Giza 90 (FGF) & 190 & 173 & 175 & 179.3 & 44 & 50 & 50 & 48.0 & 131 & 135 & 135 & 133.7 \\
\hline Mean & 270.3 & 283 & 272 & 275.1 & 72.7 & 77.2 & 78.5 & 76.1 & 199 & 211.7 & 213.8 & 208.8 \\
\hline LSD\% Blends & & & & 17.1 & & & & 6.6 & & & & 18.7 \\
\hline LSD\% Count & & & & 12.4 & & & & 5.7 & & & & 15.8 \\
\hline LSD\% Blends x Count & & & & 21.5 & & & & 8.8 & & & & 22.6 \\
\hline
\end{tabular}

,48.0 and 133.7 for the number of neps, thin places and thick places whereas the highest number of these imperfections was shown by the yarns of the blend 33\% Giza 90/ 33\% card waste/ $33 \%$ recycled fabric fibers, being 364 , 103.3 and 258.3 for the number of neps, thin and thick places respectively.

Percentage of decrease in yarn quality spun from the different blends compared to Giza 90 ranged from $15 \%$ to $35 \%$ in yarn strength, while ranged in yarn elongation from 0 to $20 \%$ while the increase in yarn CV\% (more unevenness) ranged from 4 to $15 \%$. The highest decrease in percentage of decrease in yarn quality was obtained from the blend of 33\% Giza 90/ 33\% card waste/ $33 \%$ recycled fabric fibers, whereas the least decrease in yarn quality was obtained from 75\% Giza 90 / 25\% recycled fabric fibers regardless the yarn count. It is clear that adding different portions of Giza 90 low grade virgin 

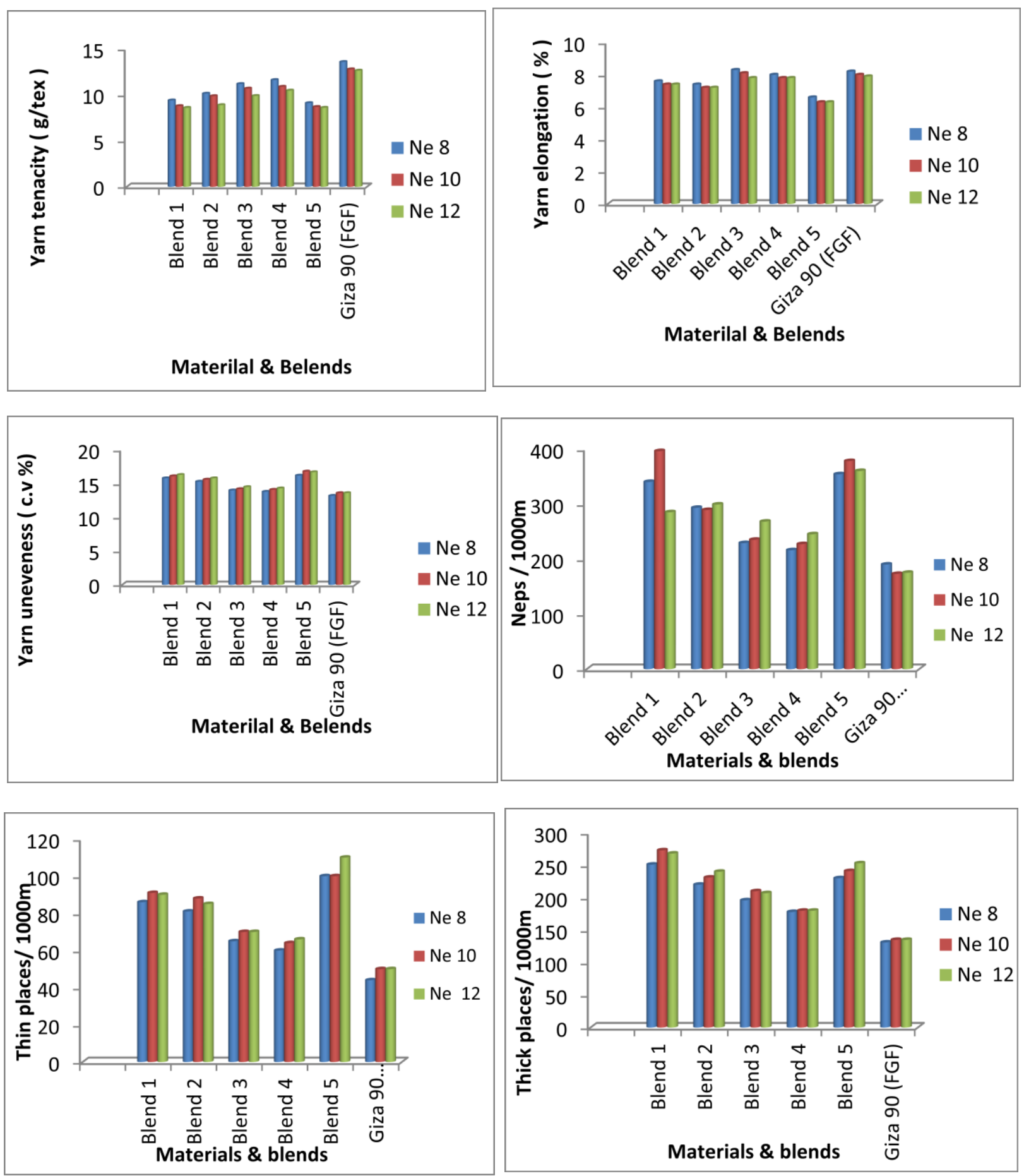

Fig.(2): Strength, Elongation, Yarn C.V\%, Neps, Thin and Thick places for the yarns spun from blends of Giza 90, card waste and recycled fabric fibers. 
fibers improved fiber quality and enabled producing coarse open end rotor yarns from these low quality materials with acceptable quality specially when the portion of the virgin fibers increased in the blend which could be considered a successful attempt to get more added value to these waste materials and to decrease the costs of the produced yarns since the wastes and recycled fibers are cheaper compared to the virgin fibers. Nityanand (1984), Stephan and Kuschel (1995), Elnouby and Kamal (2007), Halimi et al (2009) and Khan et al.(2015) came to similar findings and conclusions.

\subsection{Effect of yarn count on the quality of Giza 90, waste and recycled blended yarns \\ It is well known that yarn strength,} elongation and regularity decreases as the yarn count goes finer due to many factors specially the number of fibers in yarn cross section, twist, the setting of processing machines and fiber quality of the processed materials, in this concern data of yarn quality shown in Table (2) revealed that yarn strength, showed significant difference between $8 \mathrm{Ne}$ yarn count and $12 \mathrm{Ne}$ count only whereas the differences in yarn strength between $8 \mathrm{Ne}$ and $10 \mathrm{Ne}$ and between $10 \mathrm{Ne}$ and $12 \mathrm{Ne}$ were not significant in most cases. Yarn elongation \% did not show a specific trend to be high or low according to yarn count. On the other hand the differences in Yarn CV\% and yarn imperfections number were not statistically significant in most cases which could be due to the narrow range in the spun yarn counts being 8, 10 and $12 \mathrm{Ne}$. Sief (1984) and Arafa (2009) reported that yarn count affected significantly most of yarn quality.

\section{Conclusion}

Card waste and recycled fabric fibers could not be spun successfully to open end yarns even when decreasing the yarn count to $6 \mathrm{Ne}$, while adding portions of Giza 90 low grade virgin fibers (FGF) to form blends with these waste and recycled fibers enabled producing $8 \mathrm{Ne}, 10$ $\mathrm{Ne}$ and $12 \mathrm{Ne}$ open end rotor yarns with acceptable quality levels specially when the portion of Giza 90 was higher in the blend. The spun yarns are suitable to be used in manufacturing jeans and medium quality products. Fiber and yarn quality of the blends increased as the ratio of the virgin fibers of Giza 90 increased in the blend.

\section{REFERENCES}

ASTM D5867-05. (2005). Standard test method of measurement of physical properties of cotton fibers by High Volume Instruments. Annual Book of ASTM Standeds. (7): 02 section 7.

Arafa H. M. (2009) .Comparative study on spinning potential and yarn quality of promising crosses and some Egyptian cotton cultivars. Ph.D, Thesis, Fac. of Agric. Cairo Univ., Egypt.

Babak Y.R. and Safder E. (2013). Effect of some navels on properties of cotton/Nylon66 Blend (1:1) rotor spun yarn and wrapper formation: A comparison between Rotor and Ring Spun Yarn . J. Tex., Article ID 262635, Hindawi Publi. Corp, Tahran, Iran..

Bartolome L., Imran M. and Cho B.G. (2012). "Recent Developments in the Chemical Recycling of PET",In: Material Recycling Trends and Perspectives: 65-84, InTech Publi, Janeza train 9, 51000 Rijeta, Croatia.

Cornier R. H. (2003). Effect of recycling on material properties of polyethylene terephthalate at Various Recycling Ratios and recycling generations. Masters Thesis, Univ. of Puerto Rico, Puerto Rico.

El-Nouby G.M. and Kamel M. M. (2007). Comparison between produced yarn from recycled waste and virgin fibres in tenacity and elongation. J. Appli. Sci. Res. 3(10): 977-982

Halimi M.T., Bechir A., Mohamed B.H. and Faouzi S. (2009). Influence of spinning parameters and recovered fibers from cotton waste on the uniformity and hairiness of rotor spun yarn. J. Eng. Fibers and Fabrics, 4(3):36-44

Khan M.K.R., Sarker R.C. and Rahman H. (2015). The influence of some process parametres on rotor spun yarn quality produced from recycled cotton spinning wastes. Int'1 J. Textile Sci., 4(1): 9-19.

Nityanand A.R. (1984). Waste investigation and control for a spinning mill, The Indian Textile J. Sep. 9 (3): 79-86.

Saravanan K (2011). Environment protection by textile recycling. The Indian Textile J.(4 (1): 164-168.

Sharma R. and Joel A. (2017). Development of nonwoven fabric from recycled fibers. $\mathrm{J}$ Textile Sci. Eng., 7(2): 1-3. 
Sief M.G.(1984). Spinning performance as affected by yarn counts, twist factor and fiber properties in some Egyptian varieties. Ph.D Thesis ., Fac. Agric., Ain Shams Univ.

Snedecor G. W. and Cochran W. G. (1981).Statistical Methods, $7^{\text {th }}$ Edition Iowa State Univ., Press, Ames, Iowa, USA.

Stephan S. and Kuschel K. (1995). Recent findings on the cleanabilityof cotton. Melliand Textilberichte, 76; 206 and (English), 4 / 1995, E 49- E51.

Tereschenko K. (2012). "Waste Exchanges", $18^{\text {th }}$ International Scientific Conference Economics for Ecology, Sumy, Ukraine. Textile Journal. 27-30 : 176-177,
USTER (2001). Uster laboratory system, Description of all quality Parameters measured by uster Technologies fiba and yarin testing equipment 2001 .

Wulfhorst B. (1984). The technological and economic aspects of the recycling of wastes in modern cotton mills. Foreignedition with english supplement,Textile Praxis International, (8) : 741-743.

Yuksekkaya M.E., Celep G. Dogan G. Tercan M. and Urhan B. (2016). A comparative sudy of physical properties of yarns and fabrics produced from virgin and recycled fibers. J. Eng.Fibers and Fabrics., 11 (2): $69-76$.

\title{
إنتاج خيوط من خلطات من عوادم التسريح وخامات معا د تدوير ها مع قطن متوسط الجودة حنان محمود عرفة$$
\text { معهد بحوث القطن - مركز البحوث الزراعية ـالجيزة ـ مصر }
$$

\begin{abstract}
ملخص
أجري هذا البحث لدراسة انتاج خيوط غزل من عوادم التسريح وألياف من أقمشة معاد تدويرها بخلطيها بنسب

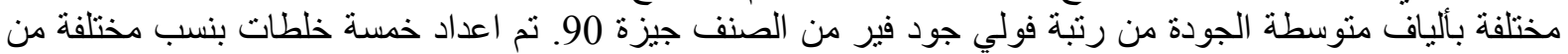

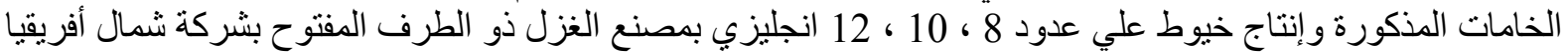

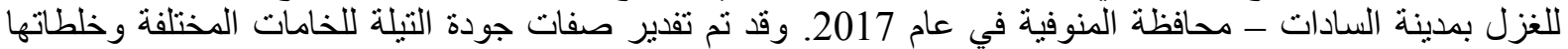

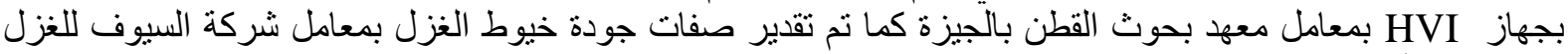
و النسيج بالأسكندرية .
\end{abstract} لالم يمكن غزل عوادم التسريح و الألياف المعاد تدوير ها حتي عندما نقص العد الي 6 إنجليزي

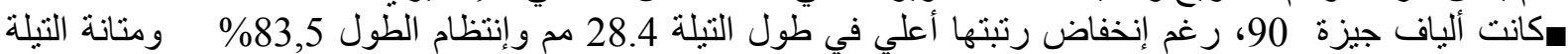

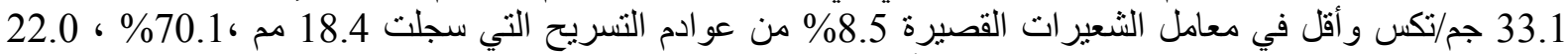

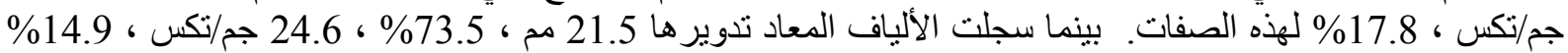

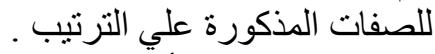

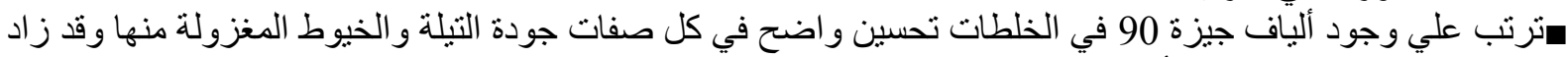

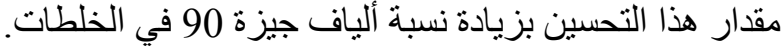

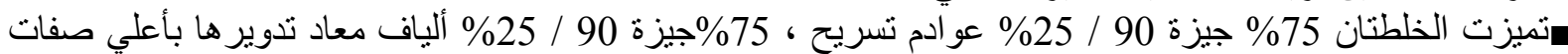

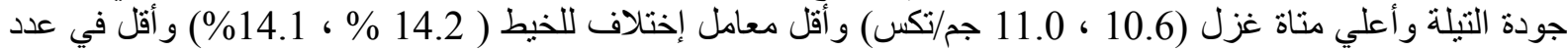

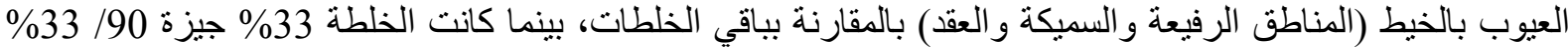

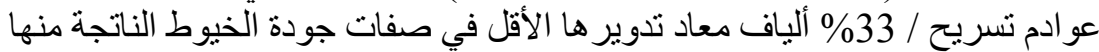

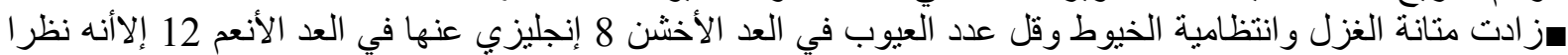

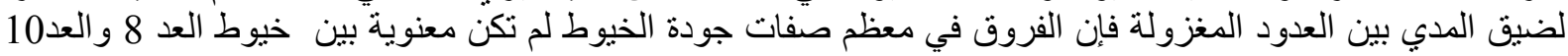
وبين خيوط العد 10 و العد 12. صأمكن بعملية خلط ألياف الرنبة المنخفضة من جيزة 90 مع عو ادم التسريح وألياف الأقمشة المعاد تدوير ها إنتاج خيوط

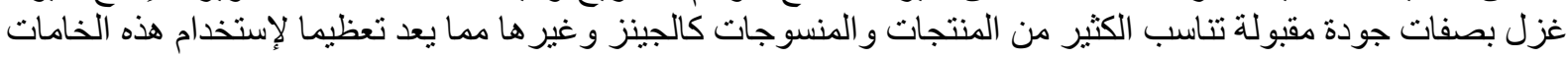
وتقليل تكلفة إنتاج هذه الخيوط. 